Hermina Święch

\title{
Sprawozdanie z objazdu naukowego Lwów i okolice
}

W dniach 30 kwietnia - 6 maja 2012 roku dziesięcioosobowa grupa studentów i doktorantów Uniwersytetu Papieskiego Jana Pawła II w Krakowie uczestniczyła w objeździe naukowym do Lwowa. Inicjatorem i głównym organizatorem wyprawy, która stanowiła uzupełnienie dwusemestralnego wykładu monograficznego, Nacjonalizm ukraiński w Galicji (Małopolsce Wschodniej) a Kościół rzymskokatolicki i Cerkiew unicka XIX/XX w., był Dziekan Wydziału Historii i Dziedzictwa Kulturowego ks. dr hab., prof. UPJPII Józef Wołczański. Opiekę naukową nad uczestnikami wyprawy roztoczył także ks. dr hab. Andrzej Bruździński, kierownik Katedry Historii Zakonów. Celem wyjazdu było zapoznanie się z historią, kulturą Lwowa, jego zabytkami, dziejami Kościoła katolickiego na tych terenach oraz wizyta w lwowskich archiwach.

Studenci wraz z opiekunami wyruszyli z Krakowa pociągiem do Przemyśla wczesnym rankiem $\mathrm{w}$ poniedziałek 30 kwietnia, a następnie autobusem $\mathrm{z}$ Przemyśla dotarli do Lwowa w godzinach popołudniowych. Grupa zatrzymała się $\mathrm{w}$ domu pielgrzyma prowadzonym przez franciszkanów konwentualnych przy ich parafialnej świątyni pw. św. Antoniego, usytuowanej przy ul. Łyczakowskiej. Należy w tym miejscu wspomnieć, iż obok katedry łacińskiej jest to jedyny lwowski kościól, czynny nieprzerwanie od 1945 roku.

Program zwiedzania został przygotowany przez ks. Dziekana i przez kolejne dni był konsekwentnie realizowany. Studenci przed wyjazdem opracowali referaty poświęcone wybranym zagadnieniom z historii miasta i jego zabytków, które prezentowali w czasie wędrówek po Lwowie. Na trasie zwiedzania znalazły się obiekty sakralne: katedra łacińska, jeden z najstarszych kościołów Lwowa, katedra ormiańska oraz cerkiew grekokatolicka św. Jura, reprezentujące trzy obrządki współistniejące ze sobą we Lwowie na przestrzeni wieków. Duże wrażenie na zwiedzających wywarły freski znanego i bardzo popularnego malarza Jana Henryka Rosena (1891-1982), znajdujące się w katedrze ormiańskiej, a w szczególności kompozycja przedstawiająca pogrzeb św. Odilona, piątego opata be- 
nedyktynów z klasztoru w Cluny. Grupa miała możliwość podziwiać twórczość wspomnianego artysty także w kaplicy dawnego seminarium łacińskiego, gdzie zachowały się jego freski wyobrażające siedem sakramentów świętych.

Uczestnicy objazdu zwiedzili również wiele lwowskich kościołów m.in. pw. św. Elżbiety, pw. św. Antoniego oraz poklasztornych świątyń, jak dawny kośció benedyktynek łacińskich, obecnie zajmowany przez grekokatolickie siostry studytki, dawny kościół Dominikanów, Jezuitów czy Bernardynów. W programie zwiedzania uwzględniono także gmach opery, Pałac Potockich, aktualnie wykorzystywany w celach muzealnych, Kamienicę Królewską z wewnętrznym arkadowym dziedzińcem, budynek Politechniki Lwowskiej, uniwersytetu oraz czytelnię Biblioteki Uniwersyteckiej, której ściany przyozdobione są freskami Juliusza Makarewicza. Jedno popołudnie studenci wraz z opiekunami przeznaczyli na wizytę na Cmentarzu Łyczakowskim oraz Cmentarzu Orląt Lwowskich.

W trakcie objazdu uczestnicy odwiedzili także dwa lwowskie archiwa: tzw. Archiwum Bernardyńskie, czyli Centralne Państwowe Archiwum Historyczne Ukrainy oraz Archiwum Państwowe Obwodu Lwowskiego, gdzie mieli możliwość przyjrzeć się archiwalnym magazynom, mieszczącym się w poklasztornych zabudowaniach.

Kulminacyjnym punktem wyjazdu było uczestnictwo w uroczystej sesji otwarcia procesu beatyfikacyjnego o. bp. Rafała Kiernickiego OFMConv (19121995), która miała miejsce 4 maja w katedrze łacińskiej. Było to bardzo ważne wydarzenie dla Kościoła lokalnego, jak i dla wspólnoty ojców franciszkanów, którzy właśnie dzięki wysiłkom o. Rafała powrócili z Polski do Lwowa w 1989 roku. Otwarcia sesji dokonał metropolita lwowski abp Mieczysław Mokrzycki w obecności postulatora procesu o. Sławomira Zielińskiego OFMConv, prowincjała krakowskiej prowincji franciszkanów o. Jarosława Zachariasza OFMConv, licznie zebranego duchowieństwa oraz wiernych. W katedrze dało się wyczuć atmosferę podniosłego wzruszenia, które szczególnie udzielało się tym spośród zebranych, którzy osobiście zetknęli się z o. Rafałem w czasie jego wieloletniego posługiwania. Zgromadzeni na początku wysłuchali referatów historyków z Uniwersytetu Papieskiego Jana Pawła II w Krakowie. Historię Kościoła katolickiego na Ukrainie sowieckiej po II wojnie światowej przedstawił ks. dr hab., prof. UPJPII Józef Wołczański. Po nim głos zabrał o. dr hab. Zdzisław Gogola OFMConv. W swym wystąpieniu przybliżył sylwetkę o. bp. Rafała Kiernickiego, który po II wojnie światowej zdecydował się pozostać we Lwowie i reprezentując swój zakon, niestrudzenie pracował jako duszpasterz i proboszcz katolickiej katedry. Po wysłuchaniu referatów nastąpiło odczytanie dekretu oraz zaprzysiężenie członków trybunału w procesie beatyfikacyjnym. Zwieńczeniem uroczystości 
była Msza św. sprawowana pod przewodnictwem metropolity lwowskiego w intencji rychłej beatyfikacji Sługi Bożego o. bp. Rafała Kiernickiego OFMConv.

Sobota, przedostatni dzień objazdu, została przeznaczona na zwiedzanie okolic Lwowa. Do grona uczestników wyprawy, po zakończeniu piątkowych uroczystości, dołączył także o. dr hab. Zdzisław Gogola OFMConv. Pierwszą miejscowością, która znalazła się na trasie, były oddalone od miasta o ok. $7 \mathrm{~km}$ Czyszki, dawny folwark franciszkanów, gdzie grupa zatrzymała się na chwilę przy kościele parafialnym pw. św. Mikołaja. Historię tego miejsca przybliżył uczestnikom o. Zdzisław Gogola OFMConv, który w bieżącym roku, wraz ze współpracownikami, wydał drukiem Kronikę parafii OO. Franciszkanów w Czyszkach 1821-1936.

Kolejnym punktem podróży był Złoczów, z siedemnastowiecznym zamkiem, należącym pierwotnie do króla Jana III Sobieskiego, a znajdującym się obecnie w dyspozycji Lwowskiej Galerii Sztuki. Następnie studenci wraz z opiekunami udali się do kościoła pw. Wniebowzięcia Najświętszej Maryi Panny, gdzie proboszcz ks. Michał Hołdowicz przedstawił w zarysie dzieje parafii, a także przybliżył postać zasłużonego duszpasterza złoczowskiej wspólnoty ks. bp. Jana Cieńskiego (1905-1992). Po wysłuchaniu prezentacji grupa została zaproszona przez księdza proboszcza oraz wikarego ks. Jerzego Tkacza na plebanię, znajdującą się w zabudowaniach po dawnym kolegium ojców pijarów, skasowanym w XVIII wieku. Po poczęstunku i chwili rozmowy z gospodarzami na tematy dotyczące posługi w parafii oraz aktualnych problemów miasta i jego mieszkańców, uczestnicy objazdu udali się do oddalonych od Złoczowa o kilkanaście kilometrów Podhorców. Studenci obejrzeli tam osiemnastowieczny barokowy kościół pw. św. Józefa i Podwyższenia Krzyża Świętego, pierwotnie zamkową, a następnie parafialną świątynię, ufundowaną przez Wacława Rzewuskiego. Duże wrażenie na zwiedzających wywarł zamek o charakterze pałacowym tzw. palazzo in fortezza. Mimo że poważnie zrujnowany i zaniedbany, wciąż stanowi świadectwo potęgi jego dawnych właścicieli: Koniecpolskich, Sobieskich, Rzewuskich i Sanguszków. Ostatnim punktem na trasie sobotniego objazdu było Olesko, gdzie na wzgórzu znajduje się dwupiętrowy zamek, wybudowany na przełomie XVI i XVII wieku. W historii zapisał się jako miejsce narodzin w 1629 roku późniejszego króla Jana III Sobieskiego. Obecnie zamek jest filią Lwowskiej Galerii Sztuki. Uczestnicy objazdu zatrzymali się także kilka chwil przed dawnym kościołem i klasztorem ojców kapucynów, usytuowanym u podnóża wzniesienia. Nie jest on udostępniany do zwiedzania, gdyż obecnie poklasztorne zabudowania wykorzystywane są jako magazyn dzieł sztuki. W drodze powrotnej do Lwowa Księża Profesorowie i studenci ponownie zostali ugoszczeni na plebanii w Złoczowie 
przez księdza proboszcza, który razem z wikarym zaprosił strudzonych historyków na smaczny obiad.

W niedzielę, 6 maja, uczestnicy objazdu wzięli jeszcze udział w porannej Mszy św. wraz z wiernymi parafii ojców franciszkanów we Lwowie, a następnie wyruszyli w drogę powrotną do Krakowa, dokąd dotarli w godzinach wieczornych. Warto dodać, że przez cały pobyt we Lwowie grupie towarzyszyła słoneczna pogoda. Pobyt we Lwowie, który stał się wyjątkową lekcją historii, z pewnością pozostawił w pamięci grupy wiele nowych doświadczeń i wspomnień. 